\title{
THE DEVELOPMENT CONCEPT OF LAW CERTAINTY ON THE BUILDING CADASTRAL TOWARD THE RIGHTS OF OWNERSHIP ON THE STRATA TITLE RIGHTS BASED ON PROPERTY LAW IN INDONESIA
}

\author{
Abraham Yazdi Martin ${ }^{1}$, Adi Sulistiyono ${ }^{2}$, Lego Karjoko ${ }^{3}$, Martin Roestamy ${ }^{4}$, Nova \\ Monaya $^{5}$ \\ ${ }^{1} \mathrm{Mr}$, Ph.D Student of Law, UNS Surakarta, originalbram@yahoo.com \\ ${ }^{2}$ Prof. Dr., Doctoral Program of Law, UNS Surakarta, adi_sumo@yahoo.co.id \\ ${ }^{3}$ Dr, Doctoral Program of Law, UNS Surakarta, legokarjoko@staff.uns.ac.id \\ ${ }^{4}$ Dr, Post-graduate School of Law, Djuanda University Bogor, mr.khotami@gmail.com \\ ${ }^{5}$ Mrs, Research Fellow, Djuanda University Bogor, novamonaya76@yahoo.com
}

\begin{abstract}
Cadastral is a system of registration of rights to the property of both movable and immovable belonging to the Property Law, including the system of registration of land rights. In the Indonesian Customary Law System, there is separate ownership of land and buildings or houses, which are caused by different ownership of the legal subject of the owner and the legal subject of the owner of the house or building. As the customary legal system is not written, then the practice of separate ownership is not explicitly registered which indicates and provides the base of ownership to the land builder. In Minangkabau custom, there is heritage land called as Ulayat, which is controlled by tribes and administered by tribal administrators, each tribal family member can build a house on tribal land that is ulayat. Likewise, in North Sumatra known as the Sultan's Grant Land derived from the Sultan's Grant can be built a house or building separately of its ownership. The building of the house or building is not registered, but it is legally recognized. This customary law practice shows the recognition of building objects on land not the owner of the building. In the practice of apartment ownership, it is recognized that a housing unit is a separate object either vertically or horizontally with the foundation of the Flats Act which is de facto separate from the land, since the land is a joint or land owned together, but the registration of ownership of the unit the flats are incorporated in a certificate of ownership rights of the apartment units, this is because the apartment regime in the registration system is subject to the land law regime which raises many problems in society. This study aims to build the concept of legal vacuum in the form of the development of building cadastral system as an alternative solution to create legal certainty on the ownership of buildings, especially in buildings Flats due to time constraints rights to the Right to Build Building which is a common land. The research method used is the normative juridical method by looking deeper into the legal postulates against the establishment of a property registration regime on buildings that are an integral part of the flats in which there is a right to unit units of flats, shared parts, shared objects, and land together.
\end{abstract}

Keywords: flat house, building, cadastral, legal certainty.

\section{BACKGROUND}

In the legal system in Indonesia, what is meant by flats is a high-rise building that is built in an environment that is divided into functionally structured parts, both horizontally and vertically and are units that can be owned and used respectively. separately, especially for shelters equipped with shared parts, shared objects, 
and common land, as regulated in Law Number 20 Year 2011 on Flats Article 1 paragraph (1) which is a change and Law Number 16 Year 1985 About Flats; it contains elements of ownership of apartment units in the form of certificates of ownership of units of flats owned by individuals, including rights attached to common land as one element of apartment ownership, land which is an integral part of joint ownership calculated based on value proportional comparison (NPP) as explained further, another element of flats ownership is among others:

The joint ownership is a part of flats owned not separately for joint use in a unit of function with units of flats. The shared part is a building structure that is not separate from the apartment building is located. The shared parts cannot be shared or utilized individually by the unit owner of the flats but is a joint right which is an integral part of the flats unit. Examples of shared parts are foundations, columns, beams, walls, floors, roofs, gutters, stairs, elevators, hallways, channels, pipes, electricity, gas, and telecommunications networks.

Shared objects are objects that are not part of the flats but are part-owned jointly not separately for shared use. Shared objects are common property, but they are separate from the structure of the apartment building. Shared objects examples are meeting rooms, plants, landscaping, social facilities buildings, places of worship, playgrounds and parking lots that are separate or incorporated into the structures of apartment buildings. And shared objects become part of the joint if built as part of the apartment building.

Common land shall be a plot of land of rights or leased land for a building used on the basis of an indivisible collective right on which an apartment stands and is set within the terms of the building permit requirements. The common land belongs not only to the owners of the apartment units located on the ground floor but to the common property of all the owners of the apartment units in the apartment. ${ }^{1}$

These four elements are entitled to be issued after one-time registration of property rights of the apartment units after passing through a series of processes by the local municipal office/district office simultaneously in a certificate of title, ${ }^{2}$ right to land and rights to apartment units declared to be born and acknowledged in the legal system of objects as a new right covering the above elements and de facto subject to the land law regime. In addition, when the certificate of ownership of the apartment unit is issued, it automatically arises the ownership of the rights to objects which are separated from each other, namely units, shared objects, shared parts and common ground and land, which is the right calculated based on the proportional comparison value (NPP) of the common land compared with the unit area in line with a legal act known as the formation of a deed of willingness to be able to know the separate parts of the objects which are united in one certificate. ${ }^{3}$

From the description above as if nothing happened with the registration of rights to the ownership rights of the apartment unit with the one-time registration, even though there are legal actions with five different objects, namely land, objects, shared parts, flat units and the Building rights (HGB) already registered first, using the term "separate but attached". In the opinion of the author, the term contains contradictions given that many cases occur once registration which results in different treatment of land as a stand-alone right and a building which in this case is a flat as a new object in the legal system of objects. In fact, the units as objects increasingly weakened their rights to follow the process of weakening the HGB due to the proportional comparison value of land from shared land that is separate but attached to the unit.

Many people who are not aware and just take it for granted, even accept it with joy, even though on the other side significant problems are waiting according to time. The problem starts with the common land ownership status, namely the land that comes from the HGB as the authorized capital of the developer to build a flat, then it will be proportionally owned by each unit owner, then what is the fate of the main HGB as a fundamental right common land there is chaos in the transfer of rights from developers to the Unit Ownership Organization (PPRS) as per Interview Result at Jakarta Housing Agency Office.

The problem becomes more complicated when the owner of the unit who is the owner of the property rights of the apartment unit wants to exploit the right to the unit that belongs to him either wants to pledge or wants to transfer such as selling, granting or making a shared deposit. The obstacle boils down to the land office for various reasons and reasons, such as The expired HGB, given the maximum period of 30 years $H G B$ and must be extended, while the process of building a flat can take up to 5 years and even more. That is, if the issuance of HGB together with the start of the development project, although it is minimal because to get the plot of land from the start of release until the issuance of HGB takes a long time, depending on the problem of the origin of the land. Likewise, the process of submitting HGB by the developer to the land office

\footnotetext{
${ }^{1}$ M R Akis and I Koeswahyono, Konsepsi Hak Milik Atas Satuan Rumah Susun Dalam Hukum Agraria (Setara Press, 2010).

${ }^{2}$ A.W.W.P. Ananta, Hukum Bisnis Properti Indonesia (PT Gramedia Widiasarana Indonesia, 2017).

${ }^{3}$ Masrofah, 'Pemberian Hak Milik Satuan Rumah Susun Diatas Beberapa Hak Guna Bangunan Perorangan', 2011, 101-19.
} 
depends on the basis of rights and relevance to the previous land acquisition. The period of 5 years, it could be since the HGB submission process that will cut the time period of the HGB is 30 years, and there is even an HGB which is only valid 20 or 25 years which is a time bomb for the next unit owner. The HGB issue that expires will be more complicated if the parent HGB as intended is built on Management Rights (HPL), both the management rights of the local government or government-owned legal entities such as national housing companies that are called PERUM-PERUMNAS (PERUMNAS).

Management rights furthermore, which is regulated in the Regulation of the Minister of Agrarian Number 9 of 1965 concerning the Conversion of State Land Rights and the Provisions on Further Policy; is the right to state land which is given its authority to the government, state or private enterprise to manage a land area for its own benefit or can also provide to third party and continuously supervise and manage the right both for its use and its use, for example; PERUMNAS for PERUMNAS region, PT. Jakarta Propertindo for Ancol, SETNEG for the ex-Kemayoran airport, or DKI Provincial Government for trade and residential-industrial area. It can be said that almost all government agencies in the region have the right of management of the area in accordance with the field and type of activities. It was determined in the law of management right, which states that management rights holders are also authorized:

a. planning the designation and use of the land;

b. uses the land for the purposes of carrying out its duties;

c. Submit parts of the land to third parties with rights use a term of 6 (six) years;

d. Receive annual income/compensation and/or mandatory money. ${ }^{4}$

One that attracts attention is; case lawsuit Mrs. Fifi Tanang, owner of the apartment unit who also served as chairman of PPRS Mangga Dua Court (PPRS-MDC) to PT. Duta Pertiwi TBK, which arises after PPRS-MDC takes care of the extension of HGB validity from where the flats were built. The amount of fees that must be issued by PPRS and the complexity of the management because it turns out the Certificates of Ownership of Flats (SHM SARUSUN) stands on the HGB is in Rights Management (HPL) on behalf of the Provincial Government. DKI which was never informed by the PT. Duta Pertiwi TBK at the time the apartment was offered up to the sale and purchase of owners of the apartment unit which became the trigger of the legal dispute between PPRS-MDC and PT. Duta Pertiwi TBK. Many communities who initially offer flats for both residential and non-residential flats (offices or commercial areas) do not get precise information about the status of the base of the rights or land rights which is the site and yard of the apartment or the commercial area was built, because the community has been lured by business benefits from marketing effects. ${ }^{5}$ However, legally neither the developer nor the marketing is transparent to the legal issues relating to land issues or the rights that burden it. For example about the existence of debt that burdened the land with mortgage rights, the existence of a certificate that has not been completed and has not been registered, or the existence of an existing period of HGB, including the right to manage the land as the case above.

On the other hand, theoretically, the unified and embedded theory of the separate rights of apartment units, both vertically and horizontally, is a consequence of increasing the complexity of the issues surrounding the property rights of the apartment units. Because every case related to the land, directly affects the ownership of the unit above it, or in this article referred to as the right to the building. ${ }^{6}$ Cadastral building which is done simultaneously with the cadastral of land integrated in unit of property of apartment unit technically indeed facilitate the registration process, but juridically raises the legal problem which until now dispute between extension process, process of transfer of HGB to PPRS, common land registration process can be said to be far from expectations or inconsistent with early promises at the time of marketing, even leaving a time bomb and causing significant cases that are actually detrimental to society and causing legal uncertainty based on the Summary of interviews with officials of Housing Agency, Notary, PPRS, and Apartment Owner of Flats in Jakarta in between January and March 2017.

This study aims to provide a solution to the legal uncertainty in the ownership of apartment unit property rights built on the right to use the building system by one-time registration on land and buildings, then how the concept of development of building cadastral system that provides legal assurance of ownership of the property rights of the unit flats in the legal system of things?

\section{RESEARCH METHODS}

The method used in this study is normative juridical, that is research using secondary data by prioritizing

\footnotetext{
${ }^{4}$ A G Kartasaputra and R G Kartasaputra, Masalah Pertanahan Di Indonesia (Bina Aksara, 1986).

${ }^{5}$ FH UI Dauri Lukman, 'ANALISA YURIDIS TERHADAP PERANAN PERS SEBAGAI SARANA PERLINDUNGAN KONSUMEN MELALUI SURAT PEMBACA ( STUDI KASUS: SENGKETA ANTARA PT . DUTA PERTIWI TbK VS PEMILIK KIOS-APARTEMEN MANGGA DUA ) Kasus Posisi Sengketa PT Duta Pertiwi Tbk vs Pemilik Kios ITC Man', 2010, 109-61.

${ }^{6}$ Ananta. Ibid
} 
research on library materials, both primary, secondary and tertiary legal materials, this research is also carried out on the principles of law and the rules of law relating to customary law, civil law, land law, and building law, by looking at empirical realities in society, in order to examine the causal relationship of each legal postulate to find the root of the main problem that will lead to legal uncertainty in building a cadastral perspective of buildings and giving the correct and independent position of the apartment unit as a separate object from the ground.

\section{RESULTS}

\subsection{Registration of Rights to Buildings and Land}

The object is every object and every right that can become the object of property rights. Furthermore, The Civil Code divides objects into intangible, movable and immovable objects, and objects that can be spent or used up as well as those that are not spent as mentioned in the Article 503, 504, and 505 Part 2 Distribution of Objects, Kitab Undang-undang Hukum Perdata, Burgerlijk Wetboek voor Indonesie. Subsequently, the object is affirmed by Article 1 paragraph (4) in the Fiduciary Guaranty Act (UUJF) number 42 of 1999 which states that: "Object is anything that can be owned and transferred, either tangible or intangible, registered or unlisted, immovable and immovable that cannot be borne by mortgage or mortgage rights."

The term "Registered Objects" and "Unlisted Objects," in the formal jurisdiction are actually known in the legal system of material since the passing of the UUJF. However, UUJF also does not provide more details on the registration of objects. Registration of rights in Indonesia is regulated by respective laws and/or related government regulations, such as land registration by PP number 24 of 1997 as a change of Government Regulation number 10 of 1961 and registration of copyright by Law number 28 of 2014, thus also Law number 13 of 2016 on Patents. Basically, in law number 28 the year 2002 jo. PP 36/2005 on building structures in article 3 states: "Data collection, including registration of buildings, is carried out during the construction permit process and periodically, intended for the orderly purposes of building and utilizing the building, providing legal certainty on the status of the building, and information systems."

Then UUBG number 28 of 2002 confirmed that in every building construction can be given ownership status of the building in addition to the land ownership status as stipulated in article 8 paragraph (1) and (2), then the regional government is obliged to record building for orderly development and utilization. According to the author including registering and issuing building certificates, so that they can be owned by individuals or legal entities as the word "everyone can own a building" indicates that the registration of buildings and issuance of building certificates is considered an obligation the regional government as mandated by UUBG article 8. It's just that the formation of government regulations (PP) mandated by article 8 paragraph (4) concerning the procedures for data collection and ownership of buildings as an independent object has not yet materialized.

Land Registration which is a refinement of the scope of land registration activities under article 1 point 1 of Government Regulation No. 24 the year 1997, which is a series of activities undertaken by the government continuously and regularly, including collection, processing, bookkeeping and presenting and maintaining data physical and juridical data in the form of maps and lists, on the plots of land and apartment units, including the provision of a certificate of title to the existing land rights and the property rights of the apartment units and certain rights who burdened him..

According to AP Parlindungan, land registration comes from the word cadaster (Dutch Cadastral) a technical term for a record, showing the area, value, and ownership (or other rights) of a parcel of land. This word is derived from Latin Capistratum which means a register or capita or unit which is made for the Roman land tax (Capotatio Terrens). In a strict sense, Cadastre is a record on lands, the value of the land and its rightholders for the benefit of taxation. Thus, Cadastre is an appropriate tool that provides the description and identification of such as well as the continuous recording of the right to land. ${ }^{7}$

According to Mhd. Yamin Lubis and Abd Rahim Lubis, in terms of the term, found the term of land registration in Latin called Capistratum, in Germany and Italy called Catastro, in France called Cadastre, in the Netherlands and also in Indonesia by Kadastrale or Cadastre. The meaning of the term in terms of Language is a register or capita or unit that is made for the Roman land tax, which means a technical term for a record that indicates to the extent, value and ownership or right holders of a plot of land, whereas a modern cadaster may be over large maps and interlinked lists. ${ }^{8}$

The title of land registration gives the impression as if the primary object of registration or the only object of

\footnotetext{
${ }^{7}$ A.P. Parlindungan, Pendaftaran Tanah di Indonesia, Mandar Maju, Bandung, 1999, P. 18-19

${ }^{8}$ Mhd. Yamin Lubis dan Abd. Rahim Lubis, Hukum Pendaftaran Tanah, Mandar Maju, Bandung, 2008, P. 18-19
} 
registration is the land. Indeed, on the collection until the presentation of physical data, the land which is the object of registration is to be sure its location, its limits, the extent in the registration map shows the physical field activity is derived from Latin Capistratum, which is the list containing the data about the land. ${ }^{9}$

The above explanation can be drawn from a synthesis that land registration has been arranged with the construction of land registration institutions since the BAL was realized as a continuation of the cadastral system implemented since the colonial era which refers to the Agrarische Wet (agrarian regulations of the Dutch era). Thus, land registration in Indonesia has been integrated into the mechanism of the Basic Agrarian Law as national agrarian law. However, land registration is dominant in building registration, because until now the registration office for the right to build a building certificate has not yet been realized, among other reasons why there are doubts about relevant agencies, such as: Ministry of Public Works and Public Housing (PUPR) formerly Ministry of Public Housing (KEMENPERA), the National Land Agency (BPN), as well as the Regional Government which in the bureaucracy have not received proper coordination and synchronization even between one agency seems to hold each other in restraint or there is institutional arrogance, there are institutions that feel superior in the registration of rights.

When compared to land and house registration in Japan, the registration of ownership status of the building is registered itself, separate from the right to land. Registration of rights to land even though proportionally the land that is part of each unit owner is listed, but the status of the land is ownership rights that are controlled and managed by the unit owners, not by the association of tenants or PPRS. Any objects that the state and parties wish to recognize, including building land by the public, can be registered at a legal registration office (called: The Judiciary or Law Office in each district) under the Japanese Ministry of Justice. Another advantage of building registration in Japan is the status of land rights is property rights that are divided proportionally based on the area ratio between the unit and land area, the latter is similar to the NPP system in Indonesia, but in Indonesia there is no thought from the government in terms of this national land agency converts the right to use the original building owned by the developer to the owner in a row, for example an SRB that has weaknesses too, because the SRB is not only an association of owners but some of them are only residents or tenants, so they cannot have access to common land ownership.

\subsection{Registration of Strata Title in Indonesia}

The right of apartment unit property is a proof of ownership right of a unit of flat's unit, shared parts, shared objects, and common land which is registered in the form of the property rights of flats (HM SARUSUN). The registration process of the certificate begins with the submission of the application file through the National Land Agency (BPN) to the Head of the Local Area, which will be followed up by a research process undertaken by several agencies, through the coordination process among related agencies with the head of BPN. The report of the research of related institutions becomes the document as the basis for the issuance of the Letter of Approval of Defense which will be ratified by the local government.

The publication of the deed of separation of flats as evidence of the separation of flats of apartment units is registered with the local Land Office for approval by the Governor. The purpose of the Deed of Separation (Pertelaan) by Developer is as the basis for the issuance of the title certificate of the apartment unit. Based on Regulation of Head of National Land Agency Number 2 the year 1989 regarding Form and Procedure of Filling and Registration of Deed of Separation of Flats shall be stipulated that this deed of separation must be registered to the local Land Office by attaching the Certificate of Right to Land and Licensed Permit.

A description of the information contained in the Separation Deed that has been ratified by the local Regional Government, becomes the basis for the issuance of the Certificate of Ownership of the Flats Unit, the certificate of ownership consists of a copy of the land of ownership rights on the unit of flats, a copy of the letter of measurement on common land, as well as pictures a unit plan for flats that clearly shows the location of the apartment project in question and the question of the size of the portion of the rights to the shared part, shared objects and common land which is an integral part. After the certificate of ownership of the apartment unit is issued, the certificate of the title of the land title on which the apartment is built must be kept in the Land Office, this provision as stipulated in the Regulation of the Head of the National Land Agency Number 4 of 1989 concerning the Form and Procedure of Making Land Book and Issuance of Ownership Rights Certificates on Flats. Strata Title/Deed of SARUSUN or Land, as a document, shows that the limits of each unit of flats shared parts, shared land objects together with proportional comparison values, which are outlined in the form of drawings and descriptions.

\footnotetext{
${ }^{9}$ B Harsono, Hukum Agraria Indonesia: Sejarah Pembentukan Undang-Undang Pokok Agraria, Isi, Dan Pelaksanaannya, Hukum Agraria Indonesia: Sejarah Pembentukan Undang-Undang Pokok Agraria, Isi, Dan Pelaksanaannya (Djambatan, 2003). P. 74
} 


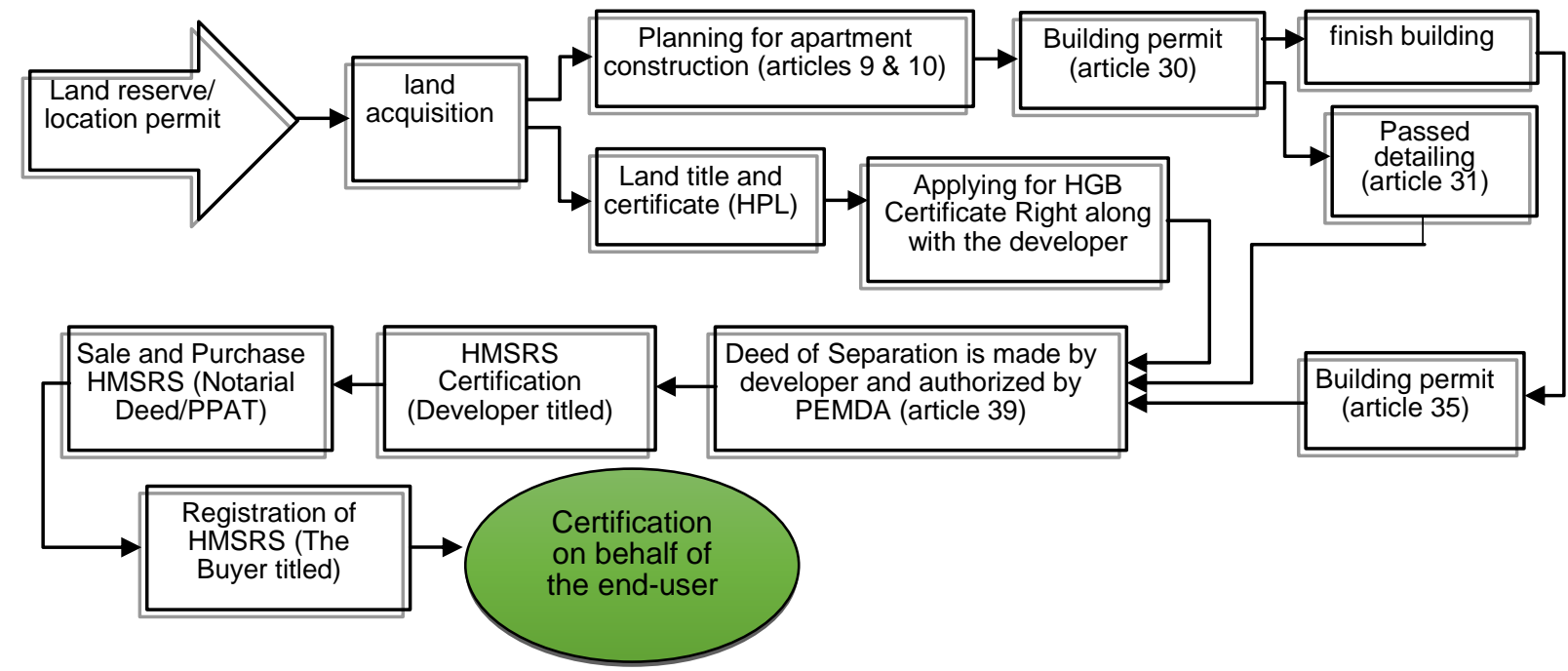

Figure 1. The process of going from HGB to SHM SARUSUN

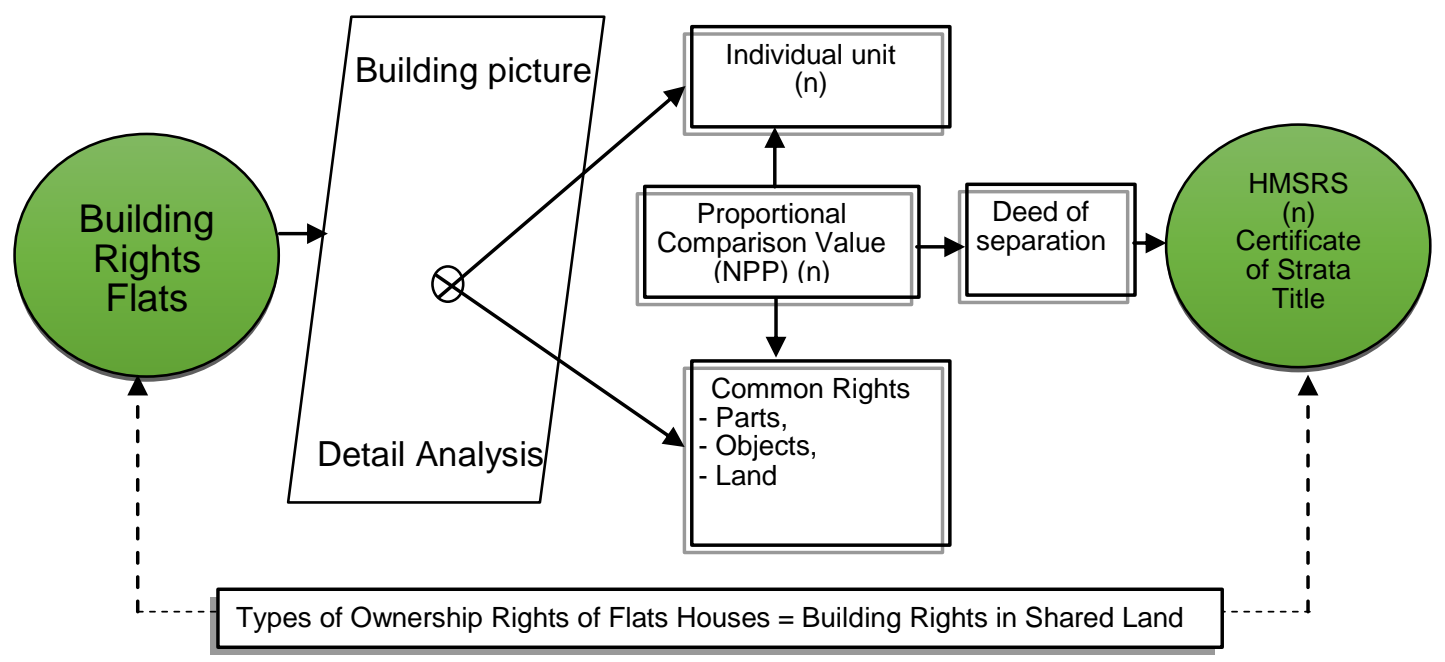

Figure 2. Detailing of Flat

From the picture above, it can be seen that there are attempts to separate the parts that are basically separated between buildings consisting of SARUSUN units, shared parts and shared land which is detailed based on the necessary drawings of buildings that have been approved by the building department to get building permits. From the details, it can be seen which is a personal right and which is a joint right. in addition to the building can also be seen two land registrations namely common land which is the land of the land of SARUSUN as the base of the initial rights and a piece of land is a part that is not separate from the owner of the unit and becomes a unit of land with HGB calculated from the results of NPP with the same status, that is a piece of HGB that is subject to the land law regime and the parent's HGB regime so that the same time period. On the other hand, as it is known that title rights are the property of units of flats, not the property of a piece of land that comes from common land, these are two legal conditions that have different consequences but come from the same law.

So in this case, the cadastral building has been implemented by the Land Office by making the building as an assesoir both in the implementation of registration and due to registration. This situation is assumed to be a legal issue due to the term "separate but embedded" as previously described. This time bomb will be turbulence in the field of property law in Indonesia when stepping on the 20-year-old HGB. This consequence is due to the fact that when the law on the apartment number 16 of 1985, the legal experts at that time put aside the principle of horizontal separation known by customary law, it prioritized the adherence principle adopted by the Civil Code (see article 500 and article 506), one of the thinkers on the land at the time, mentioned: "The buildings and plants are a unity of the land concerned, including the foundation and 
plant buildings, then mentioned the building and the plant belongs to the landowners." ${ }^{10}$ While, Mahadi mentions the principle of horizontal separation commonly found in rural communities, this principle is a principle derived from Customary Law and has a functional relationship with The Agrarian Law, which is as a source of it. ${ }^{11}$

\subsection{Due to the registration of land and buildings in flats}

As noted in the above background, legal uncertainty due to one-time registration and HGB issues of origin and application of adherence principles has led to turbulence in property law, and this potential is based on field research results, among which currently happens is the rejection of the land office for each mutation request, among others: the transfer of rights, the imposition of mortgages made by the banking world or the general public, constrained to the expiry of the term of the right to use the building unit of a flat house becomes worthless although de facto exist and acknowledged, whereas the status of the unit is the property that holds the most reliable and most complete position in the land law system, the one-time registration for two rights institutions, namely HGB and property rights has opened up dispute opportunities, and even there is a dispute up to the moment this is in addition to the case mentioned in the introduction above.

Some cases that can be listed in this paper from many of the cases studied are expected to provide an overview of actual events in the field on HGB issues and registration of buildings in a single registration at once, among others:

Table 1. The Cases of Flats and Building Cadastral Registration at once

\begin{tabular}{|c|c|c|}
\hline No. & The Parties to the Dispute & e case \\
\hline 1. & $\begin{array}{l}\text { Between Developers (PT. } \\
\text { Duta Pertiwi) with Owners } \\
\text { HMSRS (PPRS) } \\
\text { Address: } \\
\text { ITC Mangga Dua }\end{array}$ & $\begin{array}{l}\text { Case: HGB Cannot be extended } \\
\text { The expired HGB cannot be renewed even though } 90 \% \text { of HMSRS owners have } \\
\text { agreed and paid the HGB extension fee; this is because the HGB turns out to be } \\
\text { above HPL. Incident case in } 2008\end{array}$ \\
\hline 2. & $\begin{array}{l}\text { Between Developer (PT. } \\
\text { Duta Pertiwi) with owners } \\
\text { PPRS } \\
\text { Address: } \\
\text { Roxy Mas }\end{array}$ & $\begin{array}{l}\text { Case: Conflict occurs after Extension } \\
\text { There is a widespread allegation shared from the shared parts; the common land } \\
\text { is perverted by PT. Jakarta Sinar Interred is known after the extension of the } \\
\text { HGB period that has expired. Incident case in } 2004\end{array}$ \\
\hline 3. & $\begin{array}{l}\text { Between Developer (PT. } \\
\text { Duta Pertiwi) With owners } \\
\text { PPRS } \\
\text { Address: } \\
\text { ITC Cempaka Mas }\end{array}$ & $\begin{array}{l}\text { Case: HGB Can not be Extended } \\
\text { It has been } 18 \text { years PPRS stand HGB Mother never reversed the name of } \\
\text { PPRS. In addition, PT. Duta Pertiwi takes advantage of the residents from the } \\
\text { management of Water, Parking, Cafeteria, which should be the income of PPRS. } \\
\text { Incident case in } 1997 \text {. }\end{array}$ \\
\hline 4. & $\begin{array}{l}\text { Between PT. KAS, Agung } \\
\text { Podomoro Group with } \\
\text { owners PPRS } \\
\text { Address: } \\
\text { Apartemen } \quad \text { Mediterania } \\
\text { Palace } \quad \text { Residence } \\
\text { Kemayoran }\end{array}$ & $\begin{array}{l}\text { Case: Different Building Area } \\
\text { The occurrence of differences in the building area of each unit is very significant } \\
\text { and very much harm to the owner because it is not explained from the beginning } \\
\text { that the status of the land is HGB above HPL. Incident case in } 2008\end{array}$ \\
\hline 5. & $\begin{array}{l}\text { Between PERUM- } \\
\text { PERUMNAS with owners } \\
\text { PPRS } \\
\text { Address: } \\
\text { Kebon Kacang Flat, } \\
\text { Tanah Abang. }\end{array}$ & $\begin{array}{l}\text { Case: HGB Can not be Extended } \\
\text { Owners at the beginning had learned that the flats stood above the HGB above } \\
\text { the HPL on behalf of PERUM-PERUMNAS. However, when PPRS extends HGB } \\
\text { PERUM-PERUMNAS as HPL holders, it was not done with the HGB grant } \\
\text { renewal permits. Incident case in } 2008 \text {. }\end{array}$ \\
\hline 6. & $\begin{array}{l}\text { Conflict Management of } \\
\text { PPRS } \\
\text { Address: } \\
\text { Apartemen Slipi. } 2008 \\
\end{array}$ & $\begin{array}{l}\text { Case: HGB cannot be extended } \\
\text { Disputes in } 2008 \text { when the election of PPRS administrators for the 2008-2011 } \\
\text { period occurred to each other reported. HGB ended in } 2012 \text {. }\end{array}$ \\
\hline
\end{tabular}

Of the many cases studied, the authors deliberately selected the above cases to obtain a picture of the legal uncertainty that occurred in the community with the current registration system, although this research was conducted with a qualitative approach, an in-depth interview on the causes and effects of the practice of registration of the apartment has proven to create problems and potentially become a time bomb at a later time.

\footnotetext{
${ }^{10}$ Roestamy, Martin Konsep-konsep Hukum Kepemilikan Properti Bagi Asing, (Alumni, Bandung, 2013), pp. 181-182

${ }^{11}$ Mahadi, Uraian Singkat Tentang Hukum Adat Sejak RR Tahun 1854 (Alumni, 1991), p. 71
} 


\subsection{HGB Development Concept and Separate Registration}

The explanation above has shown the dominance of the land law on building law; this is because the principle of Indonesian property law adheres to two different legal principles in determining the material rights of flats. lawmakers are not aware of the domino effect which is a time bomb and in time comes the turbulence of property law in the legal system in Indonesia. It can be said that the making of a flats law does not see the customary law as a source of agrarian law if the land law regime wants to continue to dominate the building law due to the use of the vertical assessie principle. In addition, the jurists also do not see the opinion of the principle of vertical attachment quoted from the Civil Code (articles 500 to 506 ), ${ }^{12}$ although the law of the land objects and mortgage on land has been repealed by the basic agrarian law. The application of the principle of vertical attachment in the determination of certificates of ownership rights of flats is something that is detrimental to the community. Another thing if there is awareness of the government agency, in this case, is BPN, to make early preparations, about the transfer of ownership status of origin of HGB initially owned by the developer after hand over of the units, automatically, switch their rights to the association of owners/PPRS). The residents' words in this regard are recorded as one of the causes of the legal problem, due to the reluctance of non-owner occupants to think about the future of the developer's exHGB as mentioned above.

It is also necessary to think about the status of the HGB if it is pledged to finance the construction of the apartment in question so that the domination of the land law against the unit of flats can be resolved more quickly without having to harm the unit owner as happened in the aforementioned disputes. The use of adhesion principles requires comprehensive preparation, including what the developer discloses about HGB status later on what will become after hand over, the readiness of the National Land Agency as the sole authority in the issuance of apartment units, then the readiness of the SRB to accommodate all the problems surrounding the flats including responsibility for completing the HGB extension and transfer.

In order not to overlap the imposition of mortgage rights from the HGB, each hand-over from the end-user should be prepared as well as partial roya and submission or submission agreement to the end-user or if it has been established to the SRB. Developers can only form preparations for the establishment of an SRB by collecting $51 \%$ for example buyers when repaying the unit so that, preparation for ensuring the use of HGB for developer credit guarantees can be reduced by roya (cancellation) partial, where the hand-over preparation to the SRB or prospective SRB can be done by legal administration by BPN, for example by making the deed of disposal of rights for the benefit of PPRS, as illustrated below.

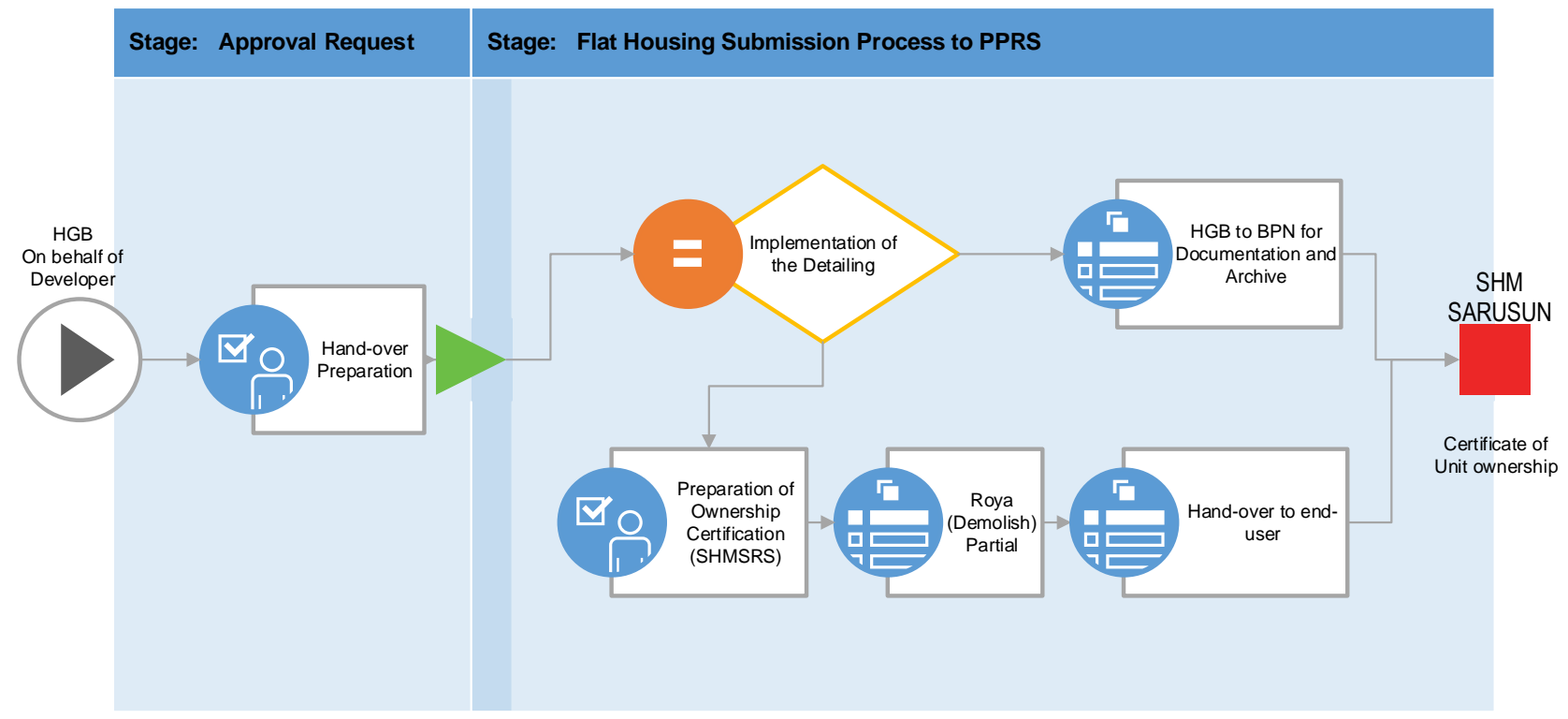

Figure 3. The Steps to HGB Hand-over

It should also be considered what about the status of HGB if it is pledged to finance the construction credit for the apartment in question? So that the domination of the land law against the unit of flats can be overcome more quickly without having to harm the unit owner as happened in the aforementioned disputes, the use of attachment principle requires comprehensive preparation, including but not limited by the developer, developer openness about HGB status will become what after hand over, the readiness of BPN

\footnotetext{
${ }^{12}$ Harsono. Op cit
} 
as the sole authority in the issuance of apartment ownership rights, then the readiness of the PPRS to accommodate all problems those around the flats including the responsibility for completing the extension and transfer of HGB.

Another solution may also be by examining more deeply the status of the HGB by making a law on HGB in which it is blessed with the existence of a flats such as a time period such as a 99-year freehold in Malaysia or a Japanese model with a Joint-Owned Property from a membership organization (kubunsuyu keng) who are responsible for managing the commonly owned land (shikici), where kubunsuyu keng becomes the coowner of the non-resident so as to have a sense of responsibility as the owner. ${ }^{13}$ This is different from Indonesia using the term residents, where the residents do not care about the termination of the term of the common land, because the occupant is not interested in the land, only concerned with the house he occupied.

As a result, the dominance of the law of the land against the law of building will actually weaken the status of property rights of the apartment units. Another problem that is never completed is the problem of land bureaucracy in this research there is a recording that as if the land office is just waiting for the extension request, should a public servant actually take proactive action with coaching to PPRS or developer how about HGB status that will end so as not becomes a time bomb, either by automating the extension or transfer of rights from the developer to the unit owner. In addition, the housing ministry office should also be pro-active in thinking about the harmful effects of the residents' membership of the PPRS; there should be an evaluation of such membership only to the owner only as kubunsuyu keng in Japan. ${ }^{14}$

By applying the principle of horizontal separation in the law of building, ${ }^{15}$ it can be done with two alternative options to prevent the weakening of property rights of the apartment units due to the end of use rights such as happened during the case described above, first if you want to use the HMSRS publishing model that occurred during this, then if you look at an excellent Japanese model is also made with the manufacture of building certification issued by the institution related to the building such as the office building or the housing office in the city/district, the certification of the building is intended to both drawing and making it a requirement of making property rights apartment units, building certification basically has a legal basis in article 12 UUBG as mentioned above. Refer to the picture below!

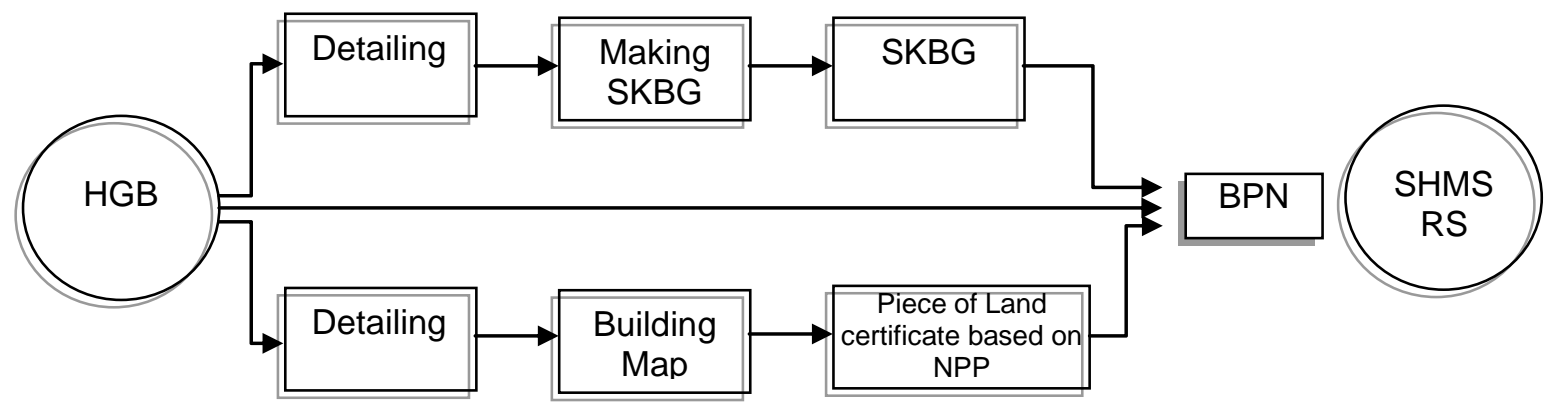

Figure 4. The Concept of HGB Development

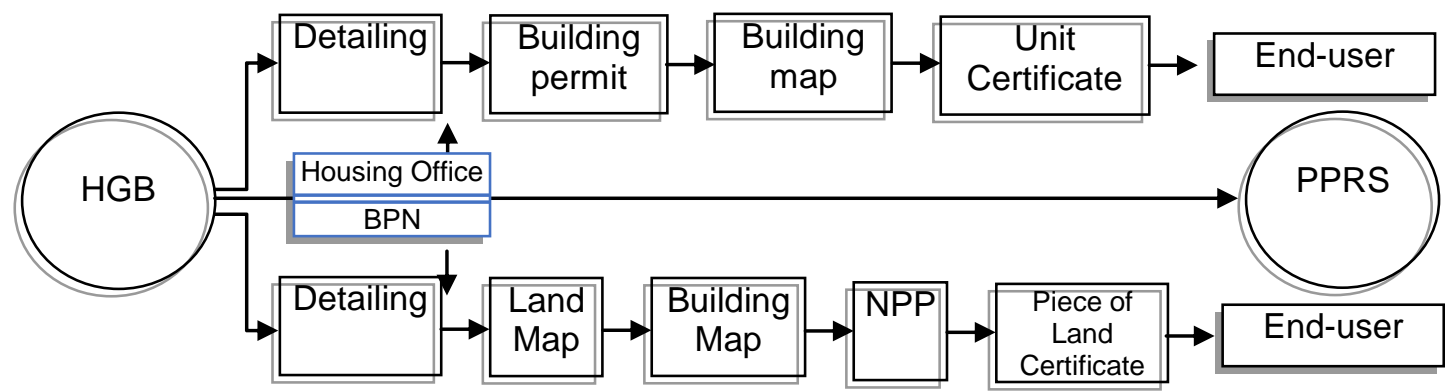

Figure 5. The Concept of Separated Registration

\footnotetext{
${ }^{13}$ Yoshitsugu Kanemoto, 'The Housing Question in Japan', Regional Science and Urban Economics, 27.August 1992 (1997), $613-41$.

${ }^{14}$ Kanemoto. Op cit.

${ }^{15}$ Martin Roestamy, 'PROVIDING AFFORDABLE HOUSING FOR LOW-INCOME PEOPLE IN INDONESIA (DEVELOPMENT OF MODEL ON HOUSING LAW)', IJASOS-International E-Journal of Advances in Social Sciences, 3.9 (2018), 1094-1103.
} 
It's just that to form an institution to certify building ownership rights is needed through government regulations, who would be better off taking the initiative or academic study of government regulation making, in this case considering the housing ministry was abolished and merged into the ministry of public works and public housing (PUPR) then the initiative should be carried out by the Ministry of PUPR, this thought considering that BPN agencies have not thought about it all this time, because they already feel they have enough expected authority. After the certification of the building is issued by the relevant agency mentioned above, then the developer can submit to the BPN for the issuance of ownership certificates belonging to the apartment unit which contains two separate legal objects, namely building objects in the form of building certificates and a piece of land which is an inseparable part of the common land which is attached together with the certificate of the building, so that in SHM SARUSUN there are two drawings, namely the image of the building and the picture of a piece of land which is an inseparable part of the common land. With the separate registration as such, there are two objects that can be guaranteed; namely a piece of land with mortgage and building certificate with the fiduciary. ${ }^{16}$

The two items, namely the registration of a house or building are carried out by the PUPR agency, for example, starting from the submission of building permits (IMB), submission of court decisions, distribution of objects and shared parts, determination of unit images in accordance with the meeting, and issuance of SKBG. With the SKBG, buying and selling are done by notarial where the developer sells such buildings including parts of land that are not separated from the common land. Regarding the land together, the developer submits the HGB to BPN, and then a detailed picture is made according to the Proportional Comparison Value (NPP), and then the issuance of the certificate is a piece of land which is an inseparable part of the shared land. concerning common land or a piece of land, it is recommended for further research, whether the rights to land can be increased to become ownership rights or building rights or other rights.

\section{CONCLUSIONS AND RECOMMENDATIONS}

The land registration system at one time and applying the principle of adherence to flats has created the potential for horizontal conflicts among stakeholders; between owners of units, PPRS, developers, and building management, because storing time bombs due to the expiration of the HGB term that is the base of rights associated with the interests of the developer and the owner of the unit due to a piece of land derived from the NPP.

The government has no readiness in applying the strata title legal system and seems to avoid taking responsibility for preparing law enforcement first, and taking into account the causal consequences of the property-ownership principle of separate apartment units and merging with one-time registration.

A more profound and comprehensive academic study involves land lawyers, property law, customary law, civil law and building law with government and developer associations to conduct a land registration system review and review the HGB term and develop a developer rights transfer model SRB, in connection with conflict interest.

\section{REFERENCE LIST}

A.P. Parlindungan, Pendaftaran Tanah di Indonesia, Mandar Maju, Bandung, 1999

Akis, M R, and I Koeswahyono, Konsepsi Hak Milik Atas Satuan Rumah Susun Dalam Hukum Agraria (Setara Press, 2010)

Ananta, A.W.W.P., Hukum Bisnis Properti Indonesia (PT Gramedia Widiasarana Indonesia, 2017)

Dauri Lukman, FH UI, 'ANALISA YURIDIS TERHADAP PERANAN PERS SEBAGAI SARANA PERLINDUNGAN KONSUMEN MELALUI SURAT PEMBACA ( STUDI KASUS : SENGKETA

ANTARA PT . DUTA PERTIWI Tbk VS PEMILIK KIOS-APARTEMEN MANGGA DUA ) Kasus Posisi Sengketa PT Duta Pertiwi Tbk vs Pemilik Kios ITC Man', 2010, 109-61

Harsono, B, Hukum Agraria Indonesia: Sejarah Pembentukan Undang-Undang Pokok Agraria, Isi, Dan Pelaksanaannya, Hukum Agraria Indonesia: Sejarah Pembentukan Undang-Undang Pokok Agraria, Isi, Dan Pelaksanaannya (Djambatan, 2003)

\footnotetext{
${ }^{16}$ M Roestamy, Hukum Jaminan Fidusia: Perlindungan Hukum Kepada Kreditor Pemegang Jaminan Fidusia Benda Tidak Terdaftar (Unida Press, 2009).
} 
Kanemoto, Yoshitsugu, 'The Housing Question in Japan', Regional Science and Urban Economics, 27 (1997), 613-41 <https://doi.org/10.1016/S0166-0462(96)02168-0>

Kartasaputra, A G, and R G Kartasaputra, Masalah Pertanahan Di Indonesia (Bina Aksara, 1986)

Mahadi, Uraian Singkat Tentang Hukum Adat Sejak RR Tahun 1854 (Alumni, 1991)

Masrofah, 'Pemberian Hak Milik Satuan Rumah Susun Diatas Beberapa Hak Guna Bangunan Perorangan', 2011, 101-19

Roestamy, M, Hukum Jaminan Fidusia: Perlindungan Hukum Kepada Kreditor Pemegang Jaminan Fidusia Benda Tidak Terdaftar (Unida Press, 2009)

Roestamy, Martin, 'PROVIDING AFFORDABLE HOUSING FOR LOW-INCOME PEOPLE IN INDONESIA (DEVELOPMENT OF MODEL ON HOUSING LAW)', IJASOS- International E-Journal of Advances in Social Sciences, 3 (2018), 1094-1103 <https://doi.org/10.18769/ijasos.391631> 